\title{
Modeling and experimental study of mechanical properties of composite plate with unidirectional reinforcement
}

\author{
Modelowanie i badania własności mechanicznych \\ płyt kompozytu o wzmocnieniu jednokierunkowym
} ADRIAN SZYMANEK
MACIEJ PARAFINIAK
KRZYSZTOF GOŁOŚ *
DOI: https://doi.org/10.17814/mechanik.2017.12.168

\begin{abstract}
In the paper, authors present results of homogenization of GFRP material properties with unidirectional reinforcement. The scope of analysis and experimental study have been averaged mechanical properties of composite: Young modulus and Poisson's ratio in orthotropic layer. Analytical calculations, computer simulation and experimental results have been presented. The work is a part of master's thesis, prepared on Faculty of Automotive and Construction Machinery Engineering, Warsaw University of Technology.
\end{abstract}

KEYWORDS: glass fiber reinforced composite GFRC, homogenization of a composite material, unidirectional reinforcement, DIC, NCORR

Composites are heterogeneous materials consisting of at least two components (reinforcements and matrix) differing in properties and playing various functions in the material. The matrix acts as a binder, due to which it gives shape to the products and transfers the loads between the fibers. In addition, it protects the reinforcement against mechanical damage. The selection of matrix is determined by the environment, in which the composite will be used. The use of fibers as a reinforcement results in high mechanical properties of the composite. Generally, they are the higher, the higher the strength parameters of fibers and the higher their volume share in the material. The resulting properties of the composite depend not only on the properties of the individual phases, but also on their quantity in the total volume of the material as well as geometrical features and the manner of distribution of the reinforcement in the matrix. Technological process plays a key role in the design of composites - its correctness determines the final properties of the material [1]. The interest in composite materials results from the fact that they have

\footnotetext{
*Inż. Adrian Szymanek (adrian.szymanek@interia.pl); dr inż. Maciej Parafiniak maciej.parafiniak@simr.pw.edu.pl - Instytut Podstaw Budowy Maszyn - Wydział Samochodów i Maszyn Roboczych Politechniki Warszawskiej; prof. dr hab. inż. Krzysztof Gołoś (k.golos@imbigs.pl) - Instytut Podstaw Budowy Maszyn - Wydział Samochodów i Maszyn Roboczych Politechnik Warszawskiej oraz Instytut Mechanizacji Budownictwa i Górnictwa Skalnego
}

relatively low specific gravity and very good strength properties, which can be created, for example, by the appropriate selection of components of a given composite. The ability to obtain the required material features is one of the most important advantages of composites [6].

\section{Homogenization of composites}

Designing the construction elements from composites requires knowledge of the mechanical properties of these materials. It is possible to predict these properties based on the microscopic structure of the composite. In this case, it is necessary to apply appropriate analytical procedures or computer simulations - this process is called homogenization [2].

The basis of the micro-mechanical analysis is the concept of a representative volume element (RVE), which is the smallest possible part or section of the material. This element, on the one hand, must take into account the volume shares of the reinforcement and the matrix, and on the other - properly reflect the macroscopic features of the whole material [4].

The simplest analytical method for the determination of substitute properties of a composite is the use of a base of mixtures or an inverse principle of mixtures [1, 2 , 4].

In the case of a one-way reinforced composite, after consideration of the stretches of elements towards the fibers, the dependence on the replacement module $E_{11}$ [3] is determined as:

$$
E_{11}=E_{\mathrm{o}} V_{\mathrm{o}}+E_{\mathrm{w}} V_{\mathrm{w}}
$$

where: $E_{o}$ - elastic constant of the matrix material, $E_{w}$ elastic constant of the fiber material, $V_{o}$ - volume matrix fraction, $V_{w}$ - volume fraction of fibers.

Similarly, when considering transverse stretching, the dependence for the equivalent module $E_{22}$ takes the form [3]:

$$
E_{22}=\frac{E_{\mathrm{o}} E_{\mathrm{w}}}{V_{\mathrm{o}} E_{\mathrm{w}}+V_{\mathrm{w}} E_{\mathrm{o}}}
$$


The replacement Poisson numbers are:

$$
\begin{gathered}
v_{12}=v_{\mathrm{o}} V_{\mathrm{o}}+v_{\mathrm{w}} V_{\mathrm{w}} \\
v_{21}=v_{12} \frac{E_{22}}{E_{11}}
\end{gathered}
$$

where: $v_{o}$ - Poisson number for matrix, $v_{w}$ - Poisson number for fiber.

For determining the Young modulus $E_{22}$ in the direction perpendicular to the reinforcement, the semiempirical model proposed by Halpin and Tsaia [3] is often used instead of the inverse principle of mixtures:

$$
E_{22}=E_{\mathrm{o}} \frac{1+\xi \eta V_{\mathrm{w}}}{1-\eta V_{\mathrm{w}}}
$$

wherein:

$$
\eta=\frac{\frac{E_{\mathrm{w}}}{E_{\mathrm{o}}}-1}{\frac{E_{\mathrm{w}}}{E_{\mathrm{o}}}+\xi}
$$

where: $\xi$ - coefficient called the reinforcement efficiency measure [2], $\eta$ - coefficient dependent on the elasticity constants of the fiber and matrix material and on the coefficient $\xi$

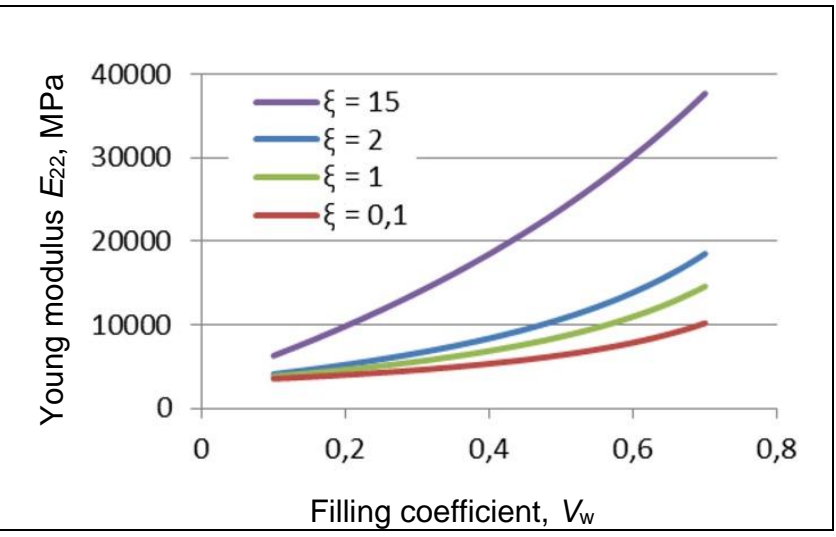

Fig. 1. The plot of the Young modulus $E_{22}$ as a function of the fill factor according to the Halpin-Tsaia model for different values of the coefficient $\xi$

Halpin and Tsai, citing the numerical calculations of Adams, Doner and Thomas, adopted the coefficient \# = 2 to determine $E_{22}$. Many other authors present in their publications their own comments and suggestions regarding the determination of this coefficient. Often, it depends on the amplification factor, the fiber arrangement and their shape and properties. It is worth noting that after substituting $\# \rightarrow \infty$ into the Halpin-Tsaia equation, it takes the form of the principle of mixtures, and for $\#=0$, it corresponds to the inverse principle of mixtures.

Fig. 1 shows the dependence of elastic modulus $E_{22}$ as a function of the fill coefficient for different values of the reinforcement efficiency \#. These values were also used to determine the substitute Poisson number $v_{21}$.
Static tension tests have been divided into two parts due to the method of measuring deformations:

- using the MFA 2 extensometer,

- using the digital image correlation (DIC) method.

The DIC is one of the contactless optical methods of deformation measurement, allowing to obtain the distribution of components of deformation on the surface of the sample. The method consists in taking a photograph of the examined element in the unloaded state and a series of photos during loading, and then in the analysis of deformation image by means of the DIC algorithm seeking the extreme of the correlation function $[5,7]$. In the studies carried out as part of this work, the DIC system used one apparatus set in the plane of the sample, which enabled obtaining two-dimensional results. Image analysis was carried out using the available NCORR software, i.e. the MATLAB application.

The advantage of the DIC system is, first of all, that a partial distribution of deformation components is obtained - in contrast to the extensometer, which averages the results from the length corresponding to the measuring base. In addition, the measurement is contactless, which is especially beneficial in the study of delicate, thin samples.

Importantly, the DIC system can be used for larger objects, and the results can be used to determine the Young modulus and Poisson's ratio.

The basic problems in the application of the DIC method include: the cumbersome process of positioning the apparatus and the necessity of applying a random pattern to the tested element by means of spray methods. One of the limitations of this method is also the relatively long time of image analysis [5].

Fig. 2 presents results of a static tensile test across the fiber samples from the composite panel, and fig. 3 an example of the sample deformation field appearance.

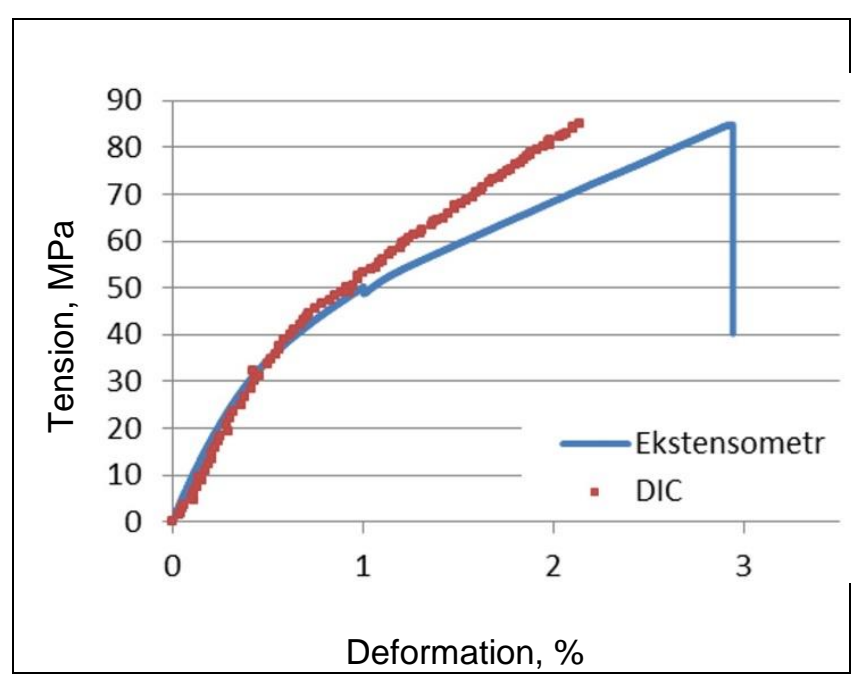

Fig. 2. Typical tension-deformation diagram for UD composite in the case of stretching across the fibers 


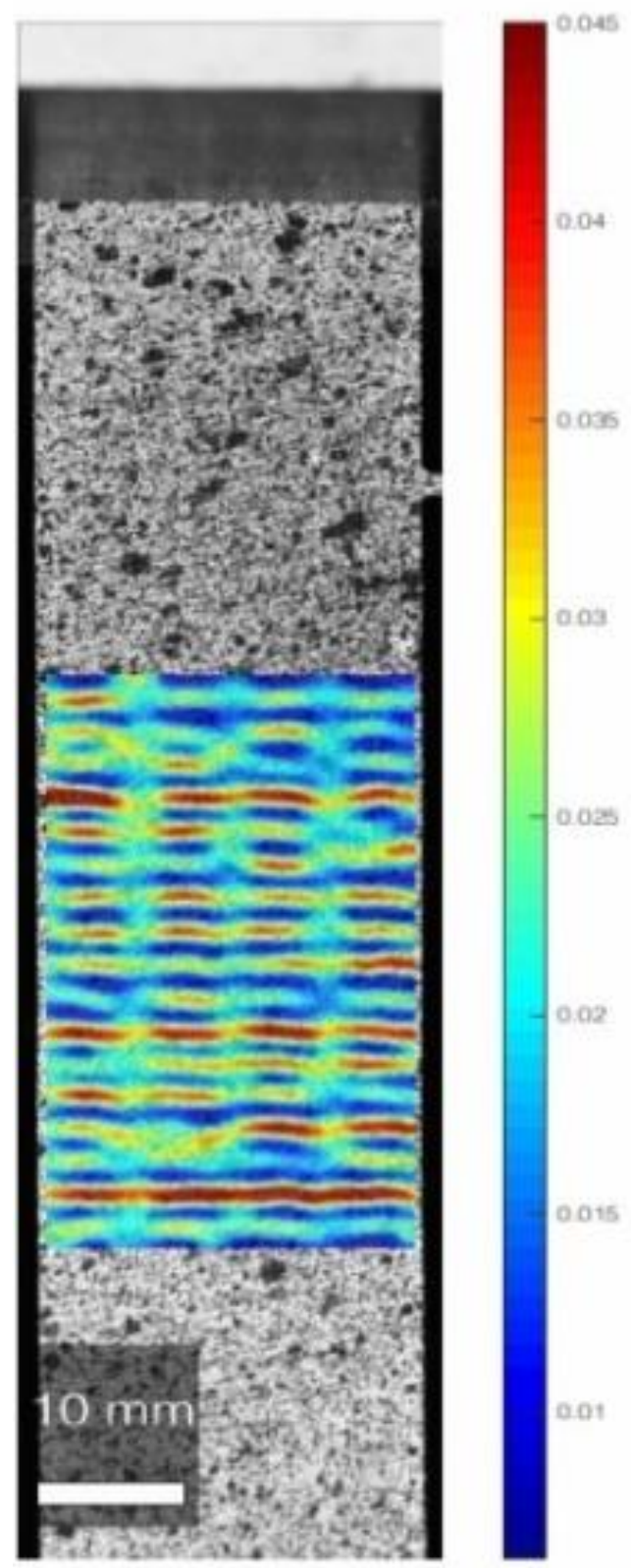

Fig. 3. Typical appearance of deformation field of UD composite sample (fibers transversely to the stretching direction)

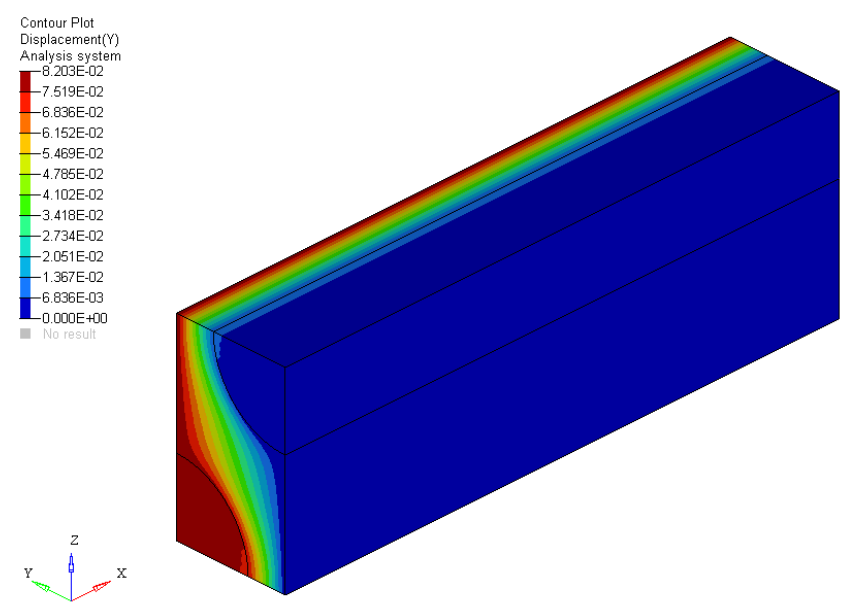

Fig. 4. Simplified RVE element - displacement in the direction $y$ (for stress $\sigma_{y}=50 \mathrm{MPa}, V_{f}=40 \%$ )

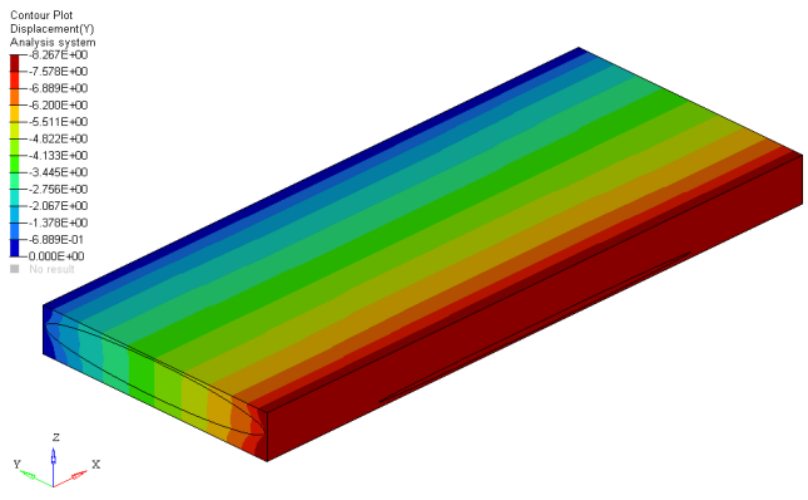

Fig. 5. The exact RVE element - displacement in the $y$ direction (for stress $\sigma_{y}=50 \mathrm{MPa}, V_{w}=44.2 \%, V_{\text {band }}=70 \%$ )

\section{Numerical simulations}

The next step was to perform a numerical analysis of the reproducible composite microstructure. The computational model was created in the HyperMesh program, and the OptiStruct program was used as a solver. Two types of RVE elements were used, which were created as a result of:

- simplified modeling - by modeling the fibers in a triangular pattern and the matrix between them,

- accurate modeling - by modeling a super-saturated fiber band and the matrix itself between the bands. Local saturation was assumed in the band at $V_{\text {band }}=70 \%$ and the super-saturation factor of the whole element at the level of $V_{w}=44.2 \%$, which corresponds to the saturation level of the composite board under test.

A band is to be understood as a piece of roving fabric, which is made of interconnected monofilaments. The fiber and the matrix were modeled as homogeneous, isotropic, while the super-saturated band in the second model - as homogeneous, orthotropic. First-order components (8-node HEX and 6-node PENTA) were used. Displacement boundary conditions have been given to simulate the effect of the rest of the material.

The simulation results, as well as experimental and analytical results are presented in figs. 4-9.

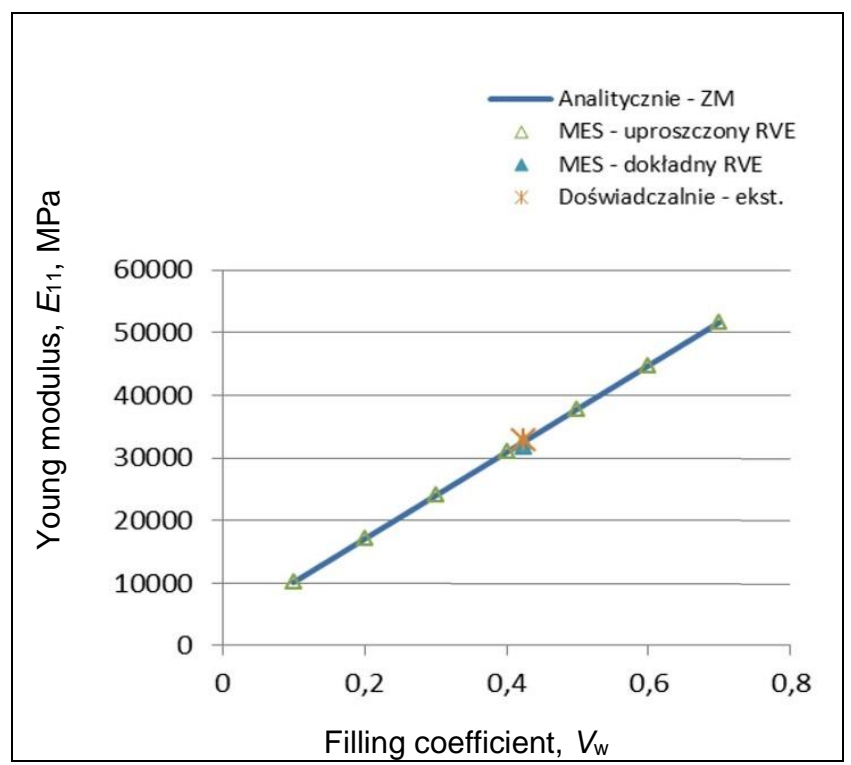

Fig. 6. Substitute Young modulus $E_{11}$ as a function of the fill factor for the composite UD 


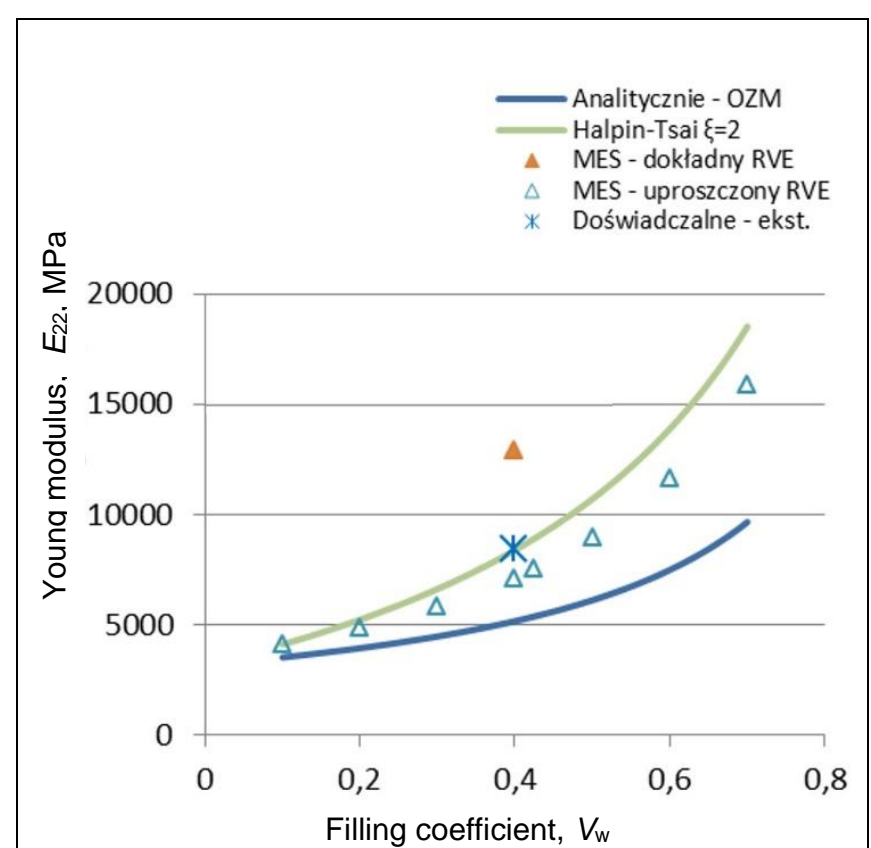

Fig. 7. Substitute Young modulus $E_{22}$ as a function of the fill factor for the composite UD

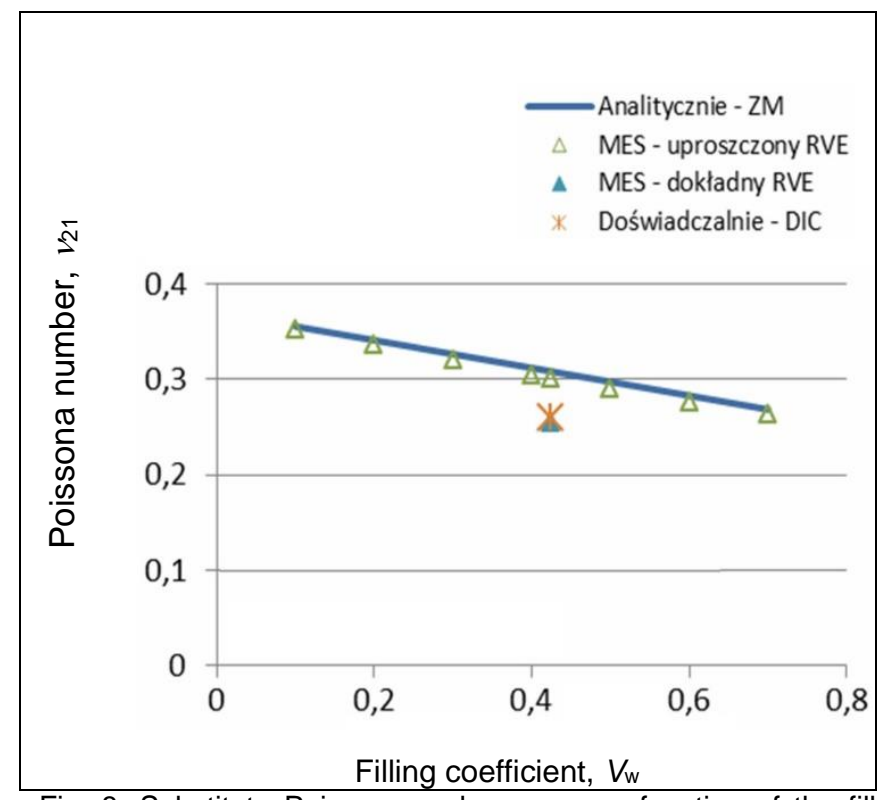

Fig. 8. Substitute Poisson number $v_{12}$ as a function of the fil factor for the composite UD

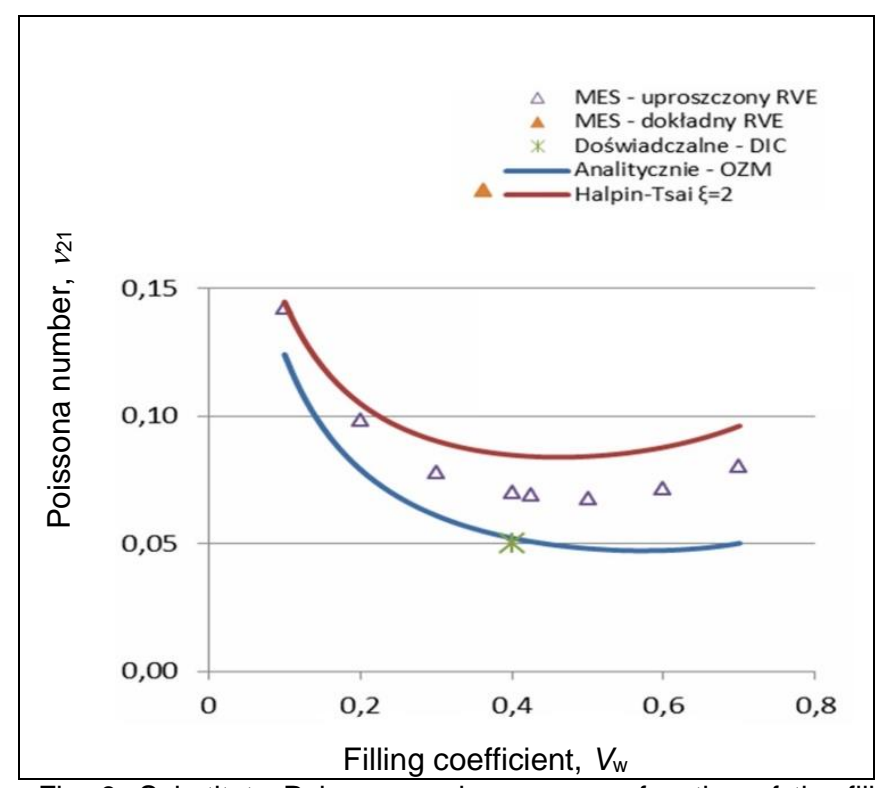

Fig. 9. Substitute Poisson number $v_{21}$ as a function of the fill factor for the composite UD

\section{Conclusions}

As part of the work, analytical calculations of substitute mechanical properties of the composite material with reinforcement of unidirectional fabric, i.e. the substitute Young modulus and substitute Poisson number, were carried out, and then their experimental verification was made. The FEM simulations of the RVE element were also performed. Figs. 6-9 graphically present the obtained experimental results along with analytical and numerical results.

The use of the DIC method to determine the components of the deformation state allowed to draw tension-deformation diagrams, and the use of an extensometer on the same sample enabled a direct comparison of the obtained results. Good consistency of results obtained with both measurement methods was confirmed. Differences in deformations exceeding $1 \%$ result from the fact that the extensometer was taken above this value, and the deformation was further calculated by the measurement system based on the traverse movement of the machine. The usefulness of the DIC system for testing composite materials has also been demonstrated, which, unlike e.g. metal samples, do not have a smooth surface. In spite of the average quality of the pattern applied to the samples, it was possible to observe local changes in the components of the deformation state that result from the geometry of the fabric.

\section{REFERENCES}

1. Boczkowska A., Krzesiński G. „Kompozyty i techniki ich wytwarzania”. Warszawa: Oficyna Wydawnicza Politechniki Warszawskiej, 2016.

2. German J. „Podstawy mechaniki kompozytów włóknistych”. Kraków: Wydawnictwo Politechniki Krakowskiej, 2001.

3. Halpin J.C., Tsai S.W. "Effect of Environmental Factors on Composite Materials". AFML-TR-67-423. 1969.

4. Jones R. "Mechanics of Composite Materials". Wydanie II. CRC Press, 1999.

5. Kowalewski Z.L., Dietrich L., Kopeć M., Szymczak T., Grzywna P. „Nowoczesne systemy optyczne w badaniach mechanicznych - budowa, działanie, zastosowania". XXII Seminarium Nieniszczące Badania Materiałów, 16-18 marca 2016 r., Zakopane, pages. 5-36.

6. Kurnik W., Tylikowski A. "Mechanika elementów laminowanych”. Warszawa: Oficyna Wydawnicza Politechniki Warszawskiej, 1997.

7. Schreier H., Orteu J.J., Sutton M.A. "Image Correlation for Shape, Motion and Deformation Measurements". Boston: Springer US, 2009 - 